\title{
When the Massive Open Online Courses, MOOC, become Hybrid at the Open University of Mauritius
}

\section{Narrainen, Gundeea}

Department of Communication Studies, Social Sciences, University Of Mauritius, Mauritius.

\begin{abstract}
With more and more courses being offered online, trainers are constantly being asked to change their teaching style. Online courses have taken another twist with innovation such as the MOOC. MOOC being non-fee paying courses by nature, are delivered mostly by established universities, course structure and management were bound to change.

With less than 10\% successful completion rate for MOOC courses and keeping in mind the Mauritian context, the Open University of Mauritius, OUM, decided to offer a hybrid MOOC. By hybrid, Daniel Peraya (2006) suggests blended courses that is online training and face to face sessions. It is more about tutoring and guiding learners rather than mere teaching.

The main objective of this paper is to show the effectiveness of a hybrid MOOC in terms of organisation and course structure. The methododoly adopted in this paper is a survey questionnaire and data from a MOODLE platform. The fact that this course has been organised in a blended mode has assured a higher completion rate. Face to face sessions helped learners to interact. The use of MOODLE as an additional platform accessssed by a restricted number of participants proved to be helpful to get aquainted to online learning.
\end{abstract}

Keywords: MOOC; MOODLE; customization; course management; innovation; 


\section{Introduction}

Distance learning as a self-instruction mode of learning is not enough. Thus trainers as well as institutions decided to opt for blended learning, a mix of online courses and on campus sessions. Blended is also refered to as hybrid. Distance learning and MOOC are similar in the sense that both are offered fully online, except that MOOC which emerged in 2008, target mass learners. With relatively a poor percentage of users successfully completing the different MOOC courses, some institutions decided to offer rather blended MOOC as opposed to standard ones.

MOOC may be considered as a trend but it is being more and more considered as an innovation in distance teaching and learning. When distance learning was launched there was a specific type of organisation about the way distance learning is conducted. Distance learning systems comprises of 'planning, organizing, leading, and controlling... institutional framework and the funding system... three major subsystems, the material subsystem involving production of materials, the service subsystem of support for learners, and the administrative subsystem for management of tutors', Rumble, 1992.

MOOC are an extension of distance learning with changing parameters. The planning phases are the same for both distance learning and MOOC. Concrning MOOC production of material is different as it is mainly focused on video lectures, support for learners is done mainly by tutors or peers and administration takes place only if the participant needs a certification.

A hybrid course is comprised of participants who are no more mere listeners and passive participants but are actors in the learning process. Greater interactions take place in such teaching context in terms of learners and tutors, peer to peer, learner and course content, learners and external resources, and integrated evaluation mechanism.

Our main objective is to demonstrate the effectiveness of a hybrid MOOC in terms of organisation and course structure, to point out the importance of face to face sessions and

ultimetaely to shed light on the fact that an additional platform, ${ }^{1}$ MOODLE, can be used for a smaller group of learners. In order to collect data, survey questionnaire and available data from a MOODLE platform were used.

\section{Tech Support: Hybrid MOOC}

The Coursera MOOC E-Learning and Digital Cultures (EDCMOOC) was launched in 2013, and was offered for a period of five weeks. This course is described as 'an xMOOC

\footnotetext{
${ }^{1}$ Modular Object Oriented Dynamic Learning Environment
} 
platform, with trainer-defined structure, content, and assignments, EDCMOOC had a social, non-hierarchical approach to the process of the MOOC itself.' Waite, Mackness, Robets and Lovegrove (2013), have described the EDCMOOC as a "hybrid" MOOC.

The eFAN MOOC 'Enseigner et Former Avec le Numérique' hosted by Cahan and Lyon Universities paved the way for the eFAN-Maths MOOC, which ran between April and June 2014. The number of enrolled learners for this course was 10,000 approximately. Participants were active in as they participated in the proposals for education projects which was the sole assessment of this course. This MOOC comprised of a MOODLE platform as support for participants to upload their projects.

The Stanford MOOC is a ten week course launched in 2012. The trainer 'wrapped' his/her course around an existing MOOC and a new version of the '2flipped classroom' emerged. Campus sessions were focused on 'interactive discussions' and 'more challenging material' Derek, Douglas, Kathryn, and Blaine (2013). The learners reacted enthusiastically to this proposed combination of MOOC and on campus course. Learners found the well designed and that the MOOC was appropriate as a self- paced learning option. Interaction was done insitu rather than through the online community. A number of concerns were flagged by users namely that of incorporating online and oncampus course mechanisms.

In 2013 the undergraduate course of Web Programming, at the University of Politehnica Timisoara, Romania, adopted a tailor-made course scenario. The blended course included face to face sessions, online multimedia course materials on Cirip group (similar to MOODLE platform), and group work. Learners 'appreciated the multimedia materials, high interactivity, collaborative activities, mobile access, openness to Social Media platforms, ${ }^{3}$ OERs and MOOC; most proposals were for increasing the number of tutorials in video format', Holotescu, Grosseck, Crețu and Naaji (2014).

\section{The Context}

The OUM in 2013 offered the Emerging Trends \& Technologies in the Virtual K-12 Classroom in collaboration with the University of California Irvine, the Education USA office and the U.S embassy of Mauritius. The target audience was primary and secondary school teachers.

\footnotetext{
2،... any blended learning strategy that requires students to prepare learning before they meet and engage with peers in purposeful activities.' http://www.uq.edu.au/teach/flipped-classroom/what-is-fc.html

3 'Open educational resources (OER) are free and openly licensed educational materials that can be used for teaching, learning, research, and other purposes.' https://wiki.creativecommons.org/wiki/What_is_OER\%3F
} 
This course is part of the 'Virtual Teaching Program' offered to trainers in the United States. In an effort to democratise education in the developing world, the United States had the mission to build up learning hubs by promoting education through MOOC.

\section{Emerging Trends \& Technologies in the Virtual K-12 Classroom on Coursera platform:}

\section{What is it?}

This Coursera course was targeted for trainers working with children between 5 to 18 years old. The course objective was to show to trainers how they could make use of technologies in order to enhance their teaching. This was a five week course. It comprised of: video lectures, lecturers slides and notes, weekly announcements, discussion forums, an assignment graded by peers, peer assessment of 3 classmates, 4 weekly quizzes comprising of 5 multiple choice questions, a final quiz comprising of 35 multiple choice questions, weekly readings, completing pre-course and post-course surveys. Coursera evaluation can be found in figure 6 .

\section{Customisation}

The OUM launched an open registration, then sorted out eligible participants and organised 6 face to face sessions. A total of 115 participants had been chosen out of the. The OUM could only accommodate 60 participants per face to face session and ran two sessions per day. Face to face sessions consisted of: content expert live presentation on the week's topic, peer presentations and answering participants' queries. A MOODLE platform was accessible to local learners. The MOODLE platform consisted of the following: video and audio format of guest speaker presentations, peer presentations, discussion forums, polls, interesting links, YouTube videos and announcements.

\begin{tabular}{|l|l|l|l|}
\hline Activities & Timing & Activities & Timing \\
\hline Welcome & $5 \mathrm{~min}$ & Course Requirements & $20 \mathrm{~min}$ \\
\hline Feedback & $15 \mathrm{~min}$ & Food for Thought & $10 \mathrm{~min}$ \\
\hline Think-Pair-Share & $10 \mathrm{~min}$ & Question Forum & $5 \mathrm{~min}$ \\
\hline Issues & $20 \mathrm{~min}$ & Guest Lecture & $30 \mathrm{~min}$ \\
\hline Wrap up & $5 \mathrm{~min}$ & Total no of minutes & $\mathbf{1 2 0} \mathbf{m i n}$ \\
\hline
\end{tabular}

Figure 1. Attendance details sample of a face to face session. Data generated by the Author. 
P. Powerpoint Mohammad Santally E-books, Learning Objects, Open Educational Resources, What next?

Mohammad Santally Video Presentation E-books, Learning Objects, Open Educational Resources and what next?

Poll: Have You ever read an eBook?

Poll: How did You find the 5 Dec Session?

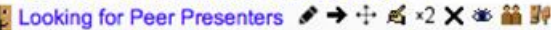

Feedback Forum: Your Take-Aways from the 5 Dec Session

Figure 2. Sample of a week content on MOODLE platform. Data generated by the Author.

\section{The OUM evaluation}

The evaluation consisted of: the portfolio, the attendance (face to face), participation on MOODLE platform and completing Coursera requirements as follows:

\begin{tabular}{|l|l|l|l|}
\hline Portfolio (75\%) & MOODLE & CAMPUS & COURSERA \\
\hline $\begin{array}{l}\text { Reflection: learning } \\
\text { experience throughout } \\
\text { the course. (15\%), }\end{array}$ & $\begin{array}{l}\text { Participation } \\
\text { discussion } \\
\text { forums(15\%), in }\end{array}$ & $\begin{array}{l}\text { attendance face } \\
\text { to face (10\%), }\end{array}$ & $\begin{array}{l}\text { completion } \\
\text { Coursera } \\
\text { requirements (10\%) }\end{array}$ \\
\hline Research Findings (10\%) & & & \\
\hline Application (40\%) & & & \\
\hline Formal Aspects (10\%) & & & \\
\hline
\end{tabular}

Figure 3. breakdown of evaluation. Data generated by the Author.

The portfolio was optional. Two best candidates were rewarded a scholarship to follow any tertiary level course of their choice at the OUM. Learners, once they had completed the MOOC requirements had to go back to their classrooms, from their learner experience of the MOOC state what they have learned and what were the difficulties encounted. They had to look for interesting articles and websites focusing on teaching and ICT. They had to state application made of the MOOC and provide learners feedback. MOOC course ended December 2013 and learners had to submit the portfolio in March 2014.

Coursera

\begin{tabular}{|c|c|c|}
\hline & $\begin{array}{l}\text { Required Final } \\
\text { Assignments }\end{array}$ & \\
\hline \multirow[t]{2}{*}{$\begin{array}{c}\text { Individual Assignment, } 3 \text { Peer Assessments, } \\
\text { Final Quiz }\end{array}$} & & Portfolio \\
\hline & $V$ & \\
\hline Statement of Accomplishment & Certificates & $\begin{array}{l}\text { Certificate of } \\
\text { Participation }\end{array}$ \\
\hline
\end{tabular}

Local

Certificate of

Figure 4. Weekly Course Requirement. Data generated by the Author 


\begin{tabular}{|c|c|}
\hline Statement of Accomplishment & Certificate of Participation \\
\hline Weekly Course Requirements & Weekly Course Requirements \\
\hline Individual Assignment & Portfolio \\
\hline 3 Peer Assessments & \\
\hline Final Quiz & $\begin{array}{c}\text { Log book diary to describe learner's learning journey } \\
\text { (Optional) }\end{array}$ \\
\hline Surveys (Optional)
\end{tabular}

Figure 5. Complete Course Requirements. Data generated by the Author.

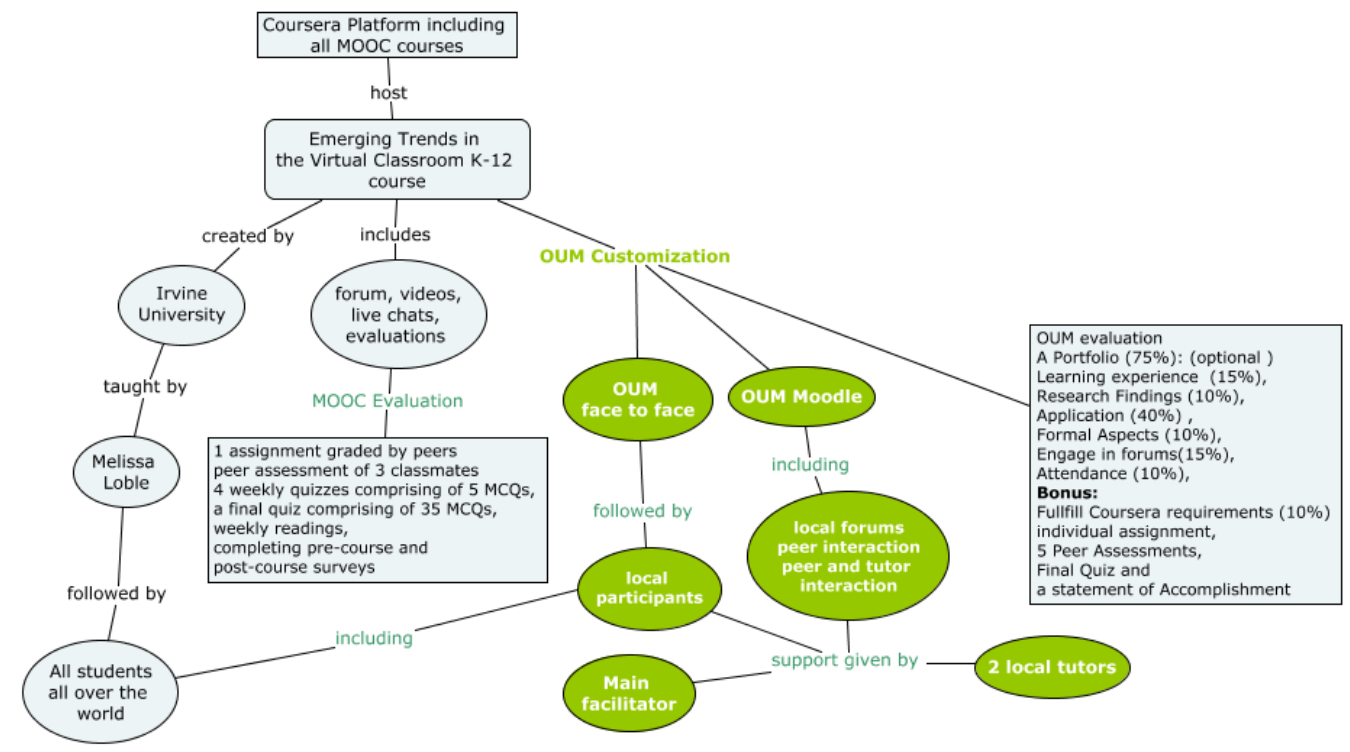

Figure 6. Overall presentation of components of the customized MOOC. Concept Map generated by the Author.

\section{Methodology}

The method used was a combination of a questionnaire and observation of learners interaction on MOODLE platform.

\section{Results and analysis}

MOODLE acted as an interface for those who were not used to technology driven platform similar to the Coursera platform. In fact, users preferred MOODLE in the first place as it was a user friendly platform. This is identified by 90 students who started getting acquainted with MOODLE platform before moving to Coursera. The participation in the MOODLE forums proved to be popular and thus learners could voice out their opinions. 
This is acknowledged by 90 students. The local discussion forums proved to be the ideal place for interaction as all learners agreed that this was the space where facilitators responded to their requests. Concerning the use of the two platforms that is MOODLE and MOOC simultaneously, learners found that this was time consuming. This was pointed out by 42 learners. Furthermore these learners stated that this mode of delivery was a constraint to manage their time as they had to be active on both platforms and be present on campus for face to face sessions.

The campus sessions was an opportunity for learners to interact live. Learners were satisfied with the content experts and peers live presentations. Learners were asked to give their feedback on the campus sessions. As weeks went by learners seldom gave their feedback to improve the on campus sessions. We thus assume that the campus sessions answered the needs of learners. Most participants found that on campus sessions were very useful and enriching.

The portfolio, the tailor-made mode of assessment, was attempted by one third of the enrolled learners. Out of 115 learners, 40 decided to submit portfolios. The quality of the portfolio varied as some learners were teachers of primary schools and had only diplomas. The level of submission was different for those who possessed a Bachelor or a Masters degree, and these were more secondary school teachers. Out of the 40 portfolios which had been submitted, 15 proved to be highly professional.

More than half of the learners found that the contents were equivalent on both platforms and this was stated by 70 learners. We note the learner engagement and willingness with the number of peer assessments corrected by each of them as follows:

\begin{tabular}{|l|l|l|l|}
\hline No of Learners & $\begin{array}{l}\text { No of corrected } \\
\text { assessments }\end{array}$ & No of Learners & $\begin{array}{l}\text { No of corrected } \\
\text { assessments }\end{array}$ \\
\hline 10 & $<5$ & 21 & 6 \\
\hline 30 & 5 & 6 & 8 \\
\hline 5 & 9 & & \\
\hline
\end{tabular}

Figure 6. No of peer assessments corrected by each learner. Data generated by the Author.

\section{Conclusion}

This research aimed at understanding the organization of a redesigned MOOC. This proposed course structure shed light on the fact that learners tend, to succeed when MOOC courses are coupled with face to face sessions which are compulsory. Learners experience a smaller platform like MOODLE before indulging in the hive which are MOOC. We point out the success rate of this MOOC with $66 \%$ of participants having successfully completed 
the course and been granted a certificate of participation. Learners have scored between $70 \%$ and $99 \%$ for the Coursera evaluation which can be considered as an encouraging trend for successful MOOC. In this precise context the MOOC was a success as it was institutionalised and well monitored. Not all MOOC have a high completion rate.

\section{References}

Aldon G., (2013). MOOC, Formations à distance, Formations hybrids.

Bruff D. O., Fisher D. H., McEwen K. E., Smith B. E., (2013). Wrapping a MOOC: Learner perception of an experiment in blended learning.

Cisel, M. et Bruillard, É. (2012). Chronique des MOOC.

Demaizière F., Grosbois M., (2014). Numérique et enseignement-apprentissage des langues en Lansad - Quand, comment, pourquoi? 29. Et les MOOC / Cloms?

Dépelteau, F. (2000). La démarche d'une recherche en sciences humaine, presse de l'Université de laval, Bruxelles, De Boeck Université.

Depover,C., (2014) Quels modèles économiques et pédagogiques pour les MOOC ?

Epelboin Y.,(2013), MOOC in Europe.

Henri F., (1993). Formation à distance, matériel pédagogique et théorie de l'éducation: la cohérence du changement.

Holotescu, C., Grosseck, G., Crețu, V. \& Naaji, A. (2014). Integrating MOOCs in Blended Courses.

Jordan K., (2014). Initial Trends in Enrolment and Completion of Massive Open Online Courses.

Minichiello F., (2013). Le phénomène des MOOC (Massive Open Online Courses).

Peraya D., (2006). Distance learning: a device of mediatized formation and communication. An approach to the processes of mediatization and mediation.

Quintin J.J. , Depover C., Degache C., (2005). Le rôle du scénario pédagogique dans l'analyse d'une formation à distance Analyse d'un scénario pédagogique a partir d'éléments de caractérisation dénis. Le cas de la formation Galanet.

Roland, N. (2014). Baladodiffusion et apprentissage mobile : approche compréhensive des usages étudiants de l'Université libre de Bruxelles.

Rosselle M., Caron P. A., Heutte J., (2014). A typology and dimensions of a description framework for MOOC.

Rumble G., (1992). The Management of Distance Learning Systems. Fundamentals of Educational Planning 43

Sandeen C., (2013). Assessment's Place in the New MOOC World.

Valdes D., (1995). Enseignement à distance et dispositifs intégrés de formation, Vers de nouvelles formes de formations :Les formations hybrides.

Waite M., Mackness J., Roberts G., Lovegrove E., (2013). Liminal Participants and Skilled Orienteers: Learner Participation in a MOOC for New Lecturers. 